\title{
Survey on the Management of ST-Segment Elevation Myocardial Infarction in Hospitals from Rural Areas of Rio Negro, Argentina
}

\author{
Encuesta sobre el manejo del infarto agudo de miocardio con elevación del segmento ST en \\ hospitales de zonas rurales de Rio Negro
}

\author{
MATíAS E. CALANDRELLII, 2 (D), JORGE L. BOCIAN¹, MARÍA E. SAAVEDRA ${ }^{3}$, JUAN P. BONIFACIO ${ }^{1,4}$, DANIEL ABRIATA ${ }^{1,4}$, \\ MARIANO TREVISÁN ${ }^{1}$
}

\begin{abstract}
Background: Information on the management of the ST-segment elevation acute myocardial infarction (STEMI) in rural areas of Argentina is scarce.

Objective: The aim of this study was to learn the availability and use of diagnostic and therapeutic resources for STEMI care in rural medical centers of Rio Negro province.

Methods: A structured, open-ended telephone survey was conducted to on-call doctors from the 8 hospitals of the Southern Line, all of them between levels of care 2 and 4 (without intensive care units).

Results: STEMI patients are attended by general practitioners, who -in half of the cases- have no specialists available to consult the ECG. In general, they do not have systematics or referral networks. Although referrals involve more than 2 hours, streptokinase is unavailable in most of the centers studied. Half of referrals are to cities that do not have interventional cardiology units for patients without medical coverage.

Conclusion: The organization and availability of resources for STEMI patients is scarce in rural areas of Rio Negro province.
\end{abstract}

Key words: ST-elevation myocardial infarction - Myocardial infarction/Epidemiology - Surveys and questionnaires - Telephone Rural population - Argentina

\section{RESUMEN}

Introducción: Es escasa la información del manejo del infarto agudo de miocardio con supradesnivel del segmento ST (IAMCEST) en zonas rurales de nuestro país.

Objetivo: Conocer la disponibilidad y utilización de recursos diagnósticos y terapéuticos en la atención del infarto agudo de miocardio con supradesnivel del segmento ST en centros médicos rurales de la provincia de Río Negro.

Material y métodos: Se realizó una encuesta telefónica, estructurada, de respuesta abierta, a médicos de guardia de los 8 hospitales de la Línea Sur, todos de nivel entre 2 y 4 (sin áreas intensivas).

Resultados: Los casos con infarto agudo de miocardio con supradesnivel del segmento ST son atendidos por generalistas, que en la mitad de los casos no tienen con quién consultar los electrocardiogramas. En general, no cuentan con sistemáticas ni redes de derivación. A pesar de que el 75\% de los centros tienen más de 2 horas de derivación, la mayoría no disponen de estreptoquinasa. La mitad de las derivaciones son a ciudades que no disponen de hemodinamia para casos sin cobertura.

Conclusión: Es escasa la organización y la disponibilidad de recursos en la atención del infarto agudo de miocardio con supradesnivel del segmento ST en zonas rurales de la provincia de Río Negro.

Palabras clave: Infarto del Miocardio con Elevación del ST - Infarto del miocardio / epidemiología - Encuestas y Cuestionarios Teléfono - Población Rural - Argentina

\section{Abbreviations}

\begin{tabular}{ll|ll} 
MV & Mechanical ventilation & SK & Streptokinase \\
AMI & Acute myocardial infarction & MICU & Mobile intensive care unit \\
STEMI & ST-segment elevation myocardial infarction & &
\end{tabular}

\footnotetext{
${ }^{1}$ Department of Cardiology. Sanatorio San Carlos, Bariloche, Río Negro

${ }^{2}$ Department of Chronic Diseases, Instituto de Investigación Clínica y Sanitaria (IECS).

${ }^{3}$ SAC Bariloche District.

${ }^{4}$ Department of Cardiology, Hospital Zonal Bariloche Dr Ramón Carrillo.
} 


\section{INTRODUCTION}

Cardiovascular diseases are still the leading cause of death in Argentina, with an annual age-adjusted rate of 180.67/10,000 inhabitants, and acute myocardial infarction (AMI) is the second cause as an individual entity. (1) Learning about the forms of presentation, timing and management of patients with ST-segment elevation acute myocardial infarction (STEMI) is not only of academic interest, but also represents an essential information for planning public health actions. Recently, a nationwide, multicenter survey reporting on these aspects has been carried out. (2) However, despite the enormous effort of the project, its representativeness has been questioned, since although $20 \%$ of all medical institutions in the country participated, the survey would reflect the activity of those with greater academic or community motivation. It is likely that the urban medical centers that did not participate are secondary hospitals, without cardiologists, and unrelated to the projects of the scientific societies. (3) Even more distant from the registries are rural environments almost $10 \%$ of the population of our country-, about which there is practically no information about AMI management. (4)

Information from two studies conducted in urban centers is available in the province of Rio Negro: several cities with intensive care units that participated in the ARGENIAM-ST registry, and the REGIBAR study in the city of Bariloche. (5) However, as is the case in the rest of the country, no data from rural areas are available. The province of Río Negro has 638,645 inhabitants, and 82,675 of them (12.9\%) are living in rural areas. The Southern Line is a succession of small towns located around the railway line that crosses the province and joins Bariloche with San Antonio Oeste, and includes from Ingeniero Jacobacci -the most populated town- with 6,261 inhabitants to Pilcaniyeu with 823 inhabitants. (6) Along the Southern Line, there are 8 hospitals exclusive for patients from these towns and surrounding scattered rural areas.

The purpose of this survey was to learn about the availability and use of diagnostic and therapeutic resources in the management of STEMI in the medical centers of the Southern Line of Rio Negro.

\section{METHODS}

A descriptive, cross-sectional study of a structured, open-ended telephone survey to on-call doctors from the 8 Southern Line hospitals, including the only zonal hospital (Jacobacci) and the 7 area hospitals (Pilcaniyeu, Comallo, Maquinchao, Los Menucos, Sierra Colorada, Ramos Mexia, and Valcheta) was performed during October 2018. All the hospitals have levels of care between 2 and 4 (Figure 1), which means that none of them have intensive care units. Questions included the available diagnostic and therapeutic resources and their use for the management of STEMI patients, including data of referrals to tertiary care centers, during 2018. Data were expressed as absolute values of frequencies and percentages for statistical analysis.

\section{Ethical considerations}

Since this was a study based on an intervention in the system -and not on the individual patient- an informed consent was not requested.

\section{RESULTS}

Acute myocardial infarction cases are always treated by general practitioners. Table 1 summarizes the demographic and geographic characteristics of the towns surveyed, and the hospital structure involved

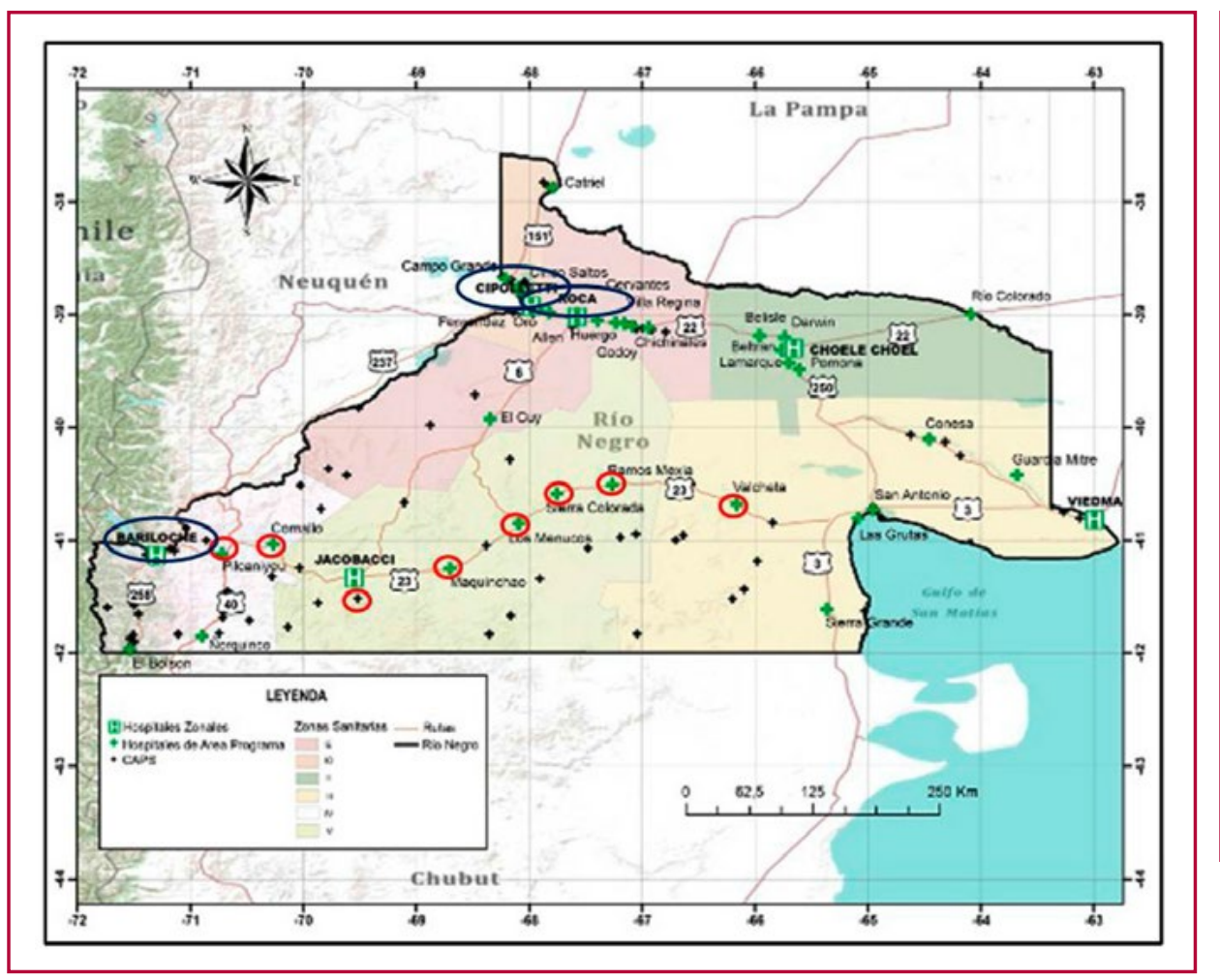

Fig. 1. Map of Rio Negro province, with the main zonal hospitals. Centers marked with an oval are cities with interventional cardiology units. The 8 Southern Line Hospitals surveyed are marked with a red circle. 
in the initial AMI care. Only 2 centers have a relatively organized referral system (Los Menucos and Sierra Colorada, with General Roca, which means 24/7 contact with cardiologists and preactivation of interventional cardiology). All hospitals have 24-hour ECG availability. Online consultation is available in $50 \%$ of the hospitals, with a cardiologist available $24 / 7$ to read the ECG and organize the initial management, although it does not necessarily function as a network. Only one hospital (12.5\% of the total) utilizes treatment systematics. Troponin assessment is unavailable in $75 \%$ of the hospitals, and of the two hospitals that do have it, one usually has no test kits. Although referral time is $>120$ minutes in $75 \%$ of the centers, streptokinase (SK) is unavailable in $85 \%$ of them. Table 2 summarizes the aspects associated with thrombolysis and referral. Only 2 centers have recently acquired SK (last 12 months). Only 1 hospital has used it, but not in 2018. Table 3 describes the indication for adjuvant treatments. Fifty percent of the hospitals refer to Bariloche and San Antonio Oeste, where an- gioplasty is unavailable for hospital cases (most of the cases on the Southern Line). All the hospitals (100\%) have an ambulance with a defibrillator available 24/7, but only one has a mobile intensive care unit (MICU) ambulance with mechanical ventilation (MV).

\section{DISCUSSION}

The findings of this survey suggest that in this rural area of our province, initial management of AMI is always performed by general practitioners who -in half of the cases- have no specialists available to consult the ECG. These hospitals do not have systematics or referral networks, most of them do not have streptokinase, and half of the referrals (with more than 120 minutes transfer) are to cities where primary angioplasty is unavailable for patients without medical coverage. As far as we could find out, these are the first data published in Argentina about AMI management in rural areas that are more than $100 \mathrm{~km}$ away from urban centers.

Should thrombolysis be performed in these rural

Table 1. Demographic and geographic characteristics of the towns surveyed and hospital structure involved in the initial ST-segment elevation acute myocardial infarction care (*according to Google Maps)

\begin{tabular}{|c|c|c|c|c|c|c|c|c|}
\hline & Pilcaniyeu & Comallo & Jaccobaci & Maquinchao & Los Menucos & $\begin{array}{c}\text { Sierra } \\
\text { Colorada }\end{array}$ & Ramos Mexia & Valcheta \\
\hline Population & 889 & 3,201 & 6,261 & 2,494 & 5,187 & 1,542 & 1,214 & 1,214 \\
\hline Nearest town & Bariloche & Bariloche & Bariloche & Bariloche & G. Roca & G. Roca & SAO & SAO \\
\hline Distance $(\mathrm{km})^{*}$ & 82 & 119 & 210 & 300 & 290 & 296 & 221 & 221 \\
\hline Time $(\min )^{*}$ & 82 & 135 & 240 & 300 & 250 & 240 & 146 & 146 \\
\hline Level of care & 3 & 3 & $4 b$ & 3 & 3 & 3 & 2 & 2 \\
\hline $\begin{array}{l}\text { Physician attending AMI } \\
\text { patient }\end{array}$ & Generalist & Generalist & Generalist & Generalist & Generalist & Generalist & Generalist & Generalist \\
\hline ECG & yes & yes & yes & yes & yes & yes & yes & yes \\
\hline Cardiologist in the town & no & no & no & no & no & no & no & no \\
\hline With systemics & no & no & no & no & no & yes & no & no \\
\hline Troponin & $\begin{array}{c}\text { no (no } \\
\text { laboratory) }\end{array}$ & no & yes & no & no & no & $\begin{array}{c}\text { no (no } \\
\text { laboratory) }\end{array}$ & $\begin{array}{c}\text { no (no } \\
\text { laboratory) }\end{array}$ \\
\hline Defibrillator & yes & yes & yes & yes & yes & yes & yes & yes \\
\hline
\end{tabular}

SAO: San Antonio Oeste.

\begin{tabular}{|c|c|c|c|c|c|c|c|c|}
\hline & Pilcaniyeu & Comallo & Jaccobaci & Maquinchao & Los Menucos & $\begin{array}{c}\text { Sierra } \\
\text { Colorada }\end{array}$ & Ramos Mexia & Valcheta \\
\hline Thrombolysis: Available? & $\begin{array}{l}\text { Yes (for the } \\
\text { last month) }\end{array}$ & no & yes & no & no & no & no & no \\
\hline Thrombolysis: Is it used? & Not used yet & no & $\begin{array}{l}\text { Not regularly } \\
\text { (not this year) }\end{array}$ & no & no & no & no & no \\
\hline Ambulances $24 / 7$ & yes & yes & yes & yes & yes & yes & yes & yes \\
\hline Ambulances with DF & yes & no & yes & yes & yes & yes & yes & yes \\
\hline MICU* & no & no & no & yes & no & no & no & no \\
\hline
\end{tabular}

* MICU: Mobile intensive care unit (with DF, MV) DF: Defibrillator. MV: Mechanical ventilation 
centers that are more than 120 minutes away from tertiary care hospitals? If the patient is in the appropriate time window and referral takes more than 120 minutes, fibrinolysis in the first health center is IA recommendation for the SAC consensus. Therefore, it should have been considered in $75 \%$ of the Southern Line hospitals.

Acute myocardial infarction has been selected by the World Health Organization as an indicator to monitor the quality of health care, using certain aspects such as belonging to a network and proper time to reperfusion. (7)

If we analyze these parameters, there is a remarkable difference in the province of Rio Negro between published results and our registry on rural hospitals. To compare both registries, it is essential to take into account that the study methodologies are very different. Considering these limitations, the reperfusion rate for STEMI patients reported in the ARGENIAMST study was $83.5 \%$ (78\% with primary angioplasty), $55.8 \%$ in the population-based REGIBAR study involving all the centers in the city of Bariloche, and according to the doctors on call, in this registry of rural centers there was no indication for thrombolysis during 2018. These figures suggest a quality gradient as far as STEMI management is concerned.

From the institutional viewpoint, the Provincial Law of Rio Negro No. 5092 -passed unanimously and promulgated in January 2016- establishes that all Area Program hospitals, under the provincial Ministry of Health, regardless of their level of care, must have fibrinolytic drugs in order to ensure immediate care for acute myocardial infarction, ensuring the provision of such drugs. It also establishes that ongoing training on early diagnosis and timely AMI treatment should be included into the annual training scheme. Reality shows that, at the time of this survey, almost none of the statements in this law were being complied with.

It is likely that improvement in STEMI patients' management in the rural area evaluated will require referral networks, as those created by Hospital El Cruce in Buenos Aires (8), by the Provincial Network for the Management of Acute Myocardial Infarction (RAPIAM) in the province of La Rioja, and by Ferrante et al. in 6 hospitals of Argentina (9), among other projects. To be considered as such, a network requires the incorporation of ECG readings by telemedicine, adapting ambulances, activating the interventional cardiology team from the referral site, referral monitoring from the receiving center, training general practitioners to perform fibrinolysis in case the estimated delay to primary angioplasty is more than 90 minutes (which would be the case in almost all the Southern Line centers). In addition, standardized systematics should be available, with cardiologists as leaders of the network and the commitment of the health authorities with this provincial-level organization.
This survey has many limitations. The disadvantages of this type of survey have been extensively described (10), the recall bias being particularly highlighted. The survey was not validated. It should also be considered that other rural areas in Argentina may not be similar to this one, so the generalization of these results should be done cautiously.

\section{CONCLUSION}

STEMI patients in this rural area of Rio Negro province are initially attended by general practitioners, who usually have no systemics, assistance, or referral networks. Although referrals in $75 \%$ of the centers take more than 2 hours, SK is unavailable in most of them, and use of thrombolysis is anecdotal. Half of the referrals are to cities where angioplasty is unavailable for patients without medical coverage. In order to solve this management deficit for STEMI patients, the creation of health care networks should be considered.

\section{Conflicts of interest}

None declared.

(See authors' conflicts of interest forms on the website/ Supplementary material)

\section{REFERENCES}

1. http://www.deis.msal.gov.ar/wp-content/uploads/2018/04/IndicadoresBasicos2017.pdf; accedido el 11/6/19

2. Gagliardi J, Charask A, Perna E, D'Imperio H, Bono J, Castillo Costa Y, y cols. Encuesta nacional de infarto agudo de miocardio con elevación del ST en la República Argentina (ARGEN-IAM-ST). Rev Argent Cardiol 2016;84:548-57. http://dx.doi.org/10.7775/rac.es.v84. i6.9508

3. Tajer C. Para hacer visible el iceberg de la mortalidad por infarto en la Argentina. Rev Argent Cardiol 2017;85:407-09. http://dx.doi. org/107775/rac.v85.i5.12466

4. http://www.ign.gob.ar/NuestrasActividades/Geografia/DatosArgentina/Poblacion2 (consultado el 20/10/2019).

5. Calandrelli ME, Caminos M, Bocian JL, Saavedra ME, Zgaib ME, Bazán A y cols. Incidencia anual y letalidad del infarto agudo de miocardio en la Ciudad de San Carlos de Bariloche. Estudio REGIBAR. Rev Argent Cardiol 2017;85:428-34. http://dx.doi.org/107775/rac. v85.i5.10398

6. http://www.rionegro.gov.ar/index.php?contID =15965, visitado el $11 / 6 / 19$.

7. Schiele F, Gale CP, Bonnefoy E, Capuano F, Claeys MJ, Danchin $\mathrm{N}$, et al. Quality indicators for acute myocardial infarction: A position paper of the Acute Cardiovascular Care Association. Eur Heart J Acute Cardiovasc Care 2017;6(1):34-59. https://doi. org/10.1177/2048872616643053

8. Silberstein A, de Abreu M, Mariani J, Kyle D, González Villamonte G, Sarmiento R y cols. Programa en red para la reperfusión del infarto con telemedicina. Rev Argent Cardiol 2015;83:187-93. http:// dx.doi.org/10.7775/rac.es.v83.i3.5595

9. Ferrante D, Spolidoro J, Caruso O, Budassi N, Onetto L, Blanco I. Mejora en la reperfusión del infarto de miocardio en Argentina. Rev Argent Salud Pública, 2013;4:31-8.

10. Carme Borrell, Maica Rodríguez-Sanz. Aspectos metodológicos de las encuestas de salud por entrevista: aportaciones de la Encuesta de Salud de Barcelona 2006. Rev Bras Epidemiol 2008; 11(supl 1): 46-57. https://doi.org/10.1590/S1415-790X2008000500005. 